\title{
Survey of selected chemical and microbiological characteristics of (plain or sweetened) natural yoghurts from the Italian market
}

\author{
Ivano DE NONI*, Luisa PELLEGRINO, Fabio MASOTTI \\ Dipartimento di Scienze e Tecnologie Alimentari e Microbiologiche, Università degli Studi di Milano, \\ via G. Celoria 2, 20133 Milan, Italy
}

(Received 9 March 2004; accepted 12 July 2004)

\begin{abstract}
Selected chemical and microbiological characteristics of plain $(n=11)$ or sweetened $(n=11)$ natural stirred yoghurts collected in the Italian market were evaluated. A strong imbalance $\left(1: 10^{3}\right.$ to $\left.1: 10^{5}\right)$ between viable cell counts of Lactobacillus delbrueckii ssp. bulgaricus (LB) and Streptococcus thermophilus (ST) was observed in five sweetened samples. Unlike the plain samples, lactic acid content was higher than that of residual galactose, suggesting the possible involvement of either galactose or added sugar in microbial catabolism. Nevertheless, isotope ratio mass spectrometry of lactic acid and sugars isolated from two sweetened samples resulted in a similar ${ }^{13} \mathrm{C} /{ }^{12} \mathrm{C}$ ratio for lactic acid and lactose, thus suggesting the catabolism of this disaccharide only. A significantly $(P<0.001)$ lower level of galactose characterised sweetened yoghurts with respect to plain ones. This feature was not related to significant production of exopolysaccharides by yoghurt bacteria since these compounds were not detected in any of the analysed sweetened samples. Pectin or starch were detected in three sweetened yoghurts despite the fact that addition of thickener to the milk base is not permitted by Italian regulation. Levels of furosine ranged from 44 to $208 \mathrm{mg} \cdot 100 \mathrm{~g}^{-1}$ protein, suggesting that milk for yoghurt manufacturing is sometimes over-heated. In this regard, evaluation of heat damage could be an additional parameter to characterise yoghurt quality.
\end{abstract}

\section{Sweetened yoghurt / thickener / heat damage / isotope ratio mass spectrometry}

Résumé - Étude de quelques caractéristiques chimiques et microbiologiques de yaourts naturels (natures ou sucrés) provenant du marché italien. Vingt-deux échantillons de yaourts naturels du type «nature » $(n=11)$ et du type «nature sucré » $(n=11)$, provenant du marché italien ont été étudiés. Dans cinq échantillons de yaourt «sucré » on a observé un fort déséquilibre $\left(1: 10^{3}\right.$ à $1: 10^{5}$ ) entre le nombre de cellules viables de Lactobacillus delbrueckii ssp. bulgaricus (LB) et de Streptococcus thermophilus (ST). Contrairement aux échantillons de type «nature », le contenu en acide lactique était plus important que celui en galactose résiduel. Cela suggère un métabolisme différent de LB et/ou de ST en présence de sucres autres que le lactose. Toutefois, la spectrométrie de masse à rapport isotopique de l'acide lactique et des sucres purifiés à partir de deux échantillons sucrés, révèle un rapport ${ }^{13} \mathrm{C} /{ }^{12} \mathrm{C}$ similaire pour l'acide lactique et le lactose, ce qui suggère le catabolisme de ce disaccharide seulement. Des valeurs significativement $(P<0.001)$ mineures du niveau de galactose caractérisent les yaourts sucrés par rapport aux yaourts natures. Ce fait n'était pas en relation avec une production significative d'exopolysaccharides par les bactéries du yaourt étant donné que ces composés n'ont pas été détectés dans les échantillons sucrés. La présence de pectine ou d'amidon a été détectée dans trois échantillons de yaourts sucrés, bien que l'addition de stabilisants ne soit pas permise en Italie. Les niveaux de furosine (44 à $208 \mathrm{mg} \cdot 100 \mathrm{~g}^{-1}$ protéine)

\footnotetext{
* Corresponding author: ivano.denoni@unimi.it
} 
suggèrent que le lait utilisé dans la fabrication de yaourt avait été soumis à des traitements thermiques excessifs. À ce propos, l'évaluation de la dénaturation thermique pouvait être un paramètre additionnel pour la caractérisation de la qualité du yaourt.

Yaourt sucré / stabilisant / dénaturation thermique / spectrométrie de masse à rapport isotopique

\section{INTRODUCTION}

Yoghurt is the fermented milk typically containing viable active cultures of Lactobacillus delbrueckii ssp. bulgaricus (LB) and Streptococcus thermophilus (ST) [13]. Yoghurt represents the most popular fermented milk, as witnessed by its worldwide distribution. In the last decade, the increasing preference of Italian consumers for slightly acidic and sweetened stirred yoghurts resulted in the progressive introduction of yoghurts with these characteristics [41].

Both enrichment of dry matter and heat treatment of the milk base are key tools for improving the texture of the final product [38]. In this regard, the heating conditions of the milk base have been widely studied with respect to improvement of the waterbinding capacity and the susceptibility to syneresis of the coagulum [11, 23, 27]. On the contrary, heat damage of yoghurt has been poorly investigated despite the fact that this aspect is becoming a paramount tool for evaluating the quality of many dairy products [12].

The heat-treated milk base is cultured with suitable strains of LB and ST in order to obtain yoghurt with specific acidity [19, 24, 40] and flavour [26]. Moreover, some strains of ST and LB are capable of producing extracelluar polysaccharides (EPS) characterised by a strong thickening power [7, 21]. Utilisation of EPS-producing strains will result in yoghurt with increased creamy texture and improved physical stability. This aspect is of particular interest in countries like Italy where thickening agents are not permitted in yoghurt manufacturing [9].

In manufacturing of sweetened yoghurt, sugars are added to the milk before heat treatment and culturing [38]. Consequently, the osmotic pressure of the milk base increases, leading to possible inhibition of yoghurt bacteria growth. Some studies have evaluated the depressive effect exerted by sucrose addition on metabolic activity and viability of LB strains [3, 4, 10]. Nevertheless, the activity of yoghurt bacteria in milk or in particular growth medium with other added sugars has been investigated less [1, $2,6]$.

This work reports on selected chemical and microbiological characteristics of both plain and sweetened stirred yoghurts collected in the Italian market. Further investigations were addressed (i) to ascertain the possible fermentation of added sugars in sweetened yoghurts, (ii) to point out illegal addition of thickeners, and finally (iii) to evaluate whether molecules which form in the milk base during heat treatment can represent reliable indicators of the extent of heat damage in yoghurt.

\section{MATERIALS AND METHODS}

\subsection{Yoghurt samples}

Twenty-two commercial samples of stirred-type yoghurt, including 11 plain $(p)$ and 11 sweetened $(s)$, were collected in the Italian market. Samples were from 16 manufacturers (14 Italian and 2 German, labelled as A-S) who cover more than $95 \%$ of the Italian market. All samples were analysed within $10 \mathrm{~d}$ from manufacturing.

Experimental skimmed or whole plain yoghurts were prepared from raw bulk milk concentrated by vacuum evaporation to give a total solids-non-fat content of 11.0 or 
$10.4 \%$, respectively. Batches of milk were heat treated at $90{ }^{\circ} \mathrm{C}$ for 30 min (milk samples were taken after $5,10,20$ or $30 \mathrm{~min}$ ) at the industrial plant of a leading Italian yoghurt manufacturer (named as A). Heattreated milk was inoculated with a $3 \%$ culture of ST and LB (1:1 combination) and incubated at $42{ }^{\circ} \mathrm{C}$ for $6 \mathrm{~h}$ until $1.3 \mathrm{~g}$ lactic acid per $100 \mathrm{~g}$ yoghurt (pH 3.7) were produced. The specific physiological characteristics of the strains of ST and LB used were not given by the manufacturer. After stirring, the yoghurts were cooled at $4{ }^{\circ} \mathrm{C}$, packaged and kept refrigerated until analysis. Fat and protein contents were 0.8 and $4.0 \mathrm{~g} \cdot 100 \mathrm{~g}^{-1}$ for skimmed yoghurt and 3.9 and $3.6 \mathrm{~g} \cdot 100 \mathrm{~g}^{-1}$ for whole milk samples, respectively.

\subsection{Chemical analyses}

\subsubsection{Lactic acid}

One gram of yoghurt was diluted with $20 \mathrm{~mL}$ pure grade water (Millipore, Bedford MA, USA), with $1 \mathrm{~mL}$ Carrez I and $1 \mathrm{~mL}$ Carrez II solutions added, and neutralised to $\mathrm{pH} 7.0$ with $0.1 \mathrm{~N} \mathrm{NaOH}$, then made up to $50 \mathrm{~mL}$ with water. After keeping it at room temperature for $15 \mathrm{~min}$, the sample was filtered through a paper filter (Schleicher \& Schuell, Dassel, Germany) and the filtrate analysed for $\mathrm{D}(-)$ and $\mathrm{L}(+)$-lactic acid content $\left(\mathrm{g} \cdot 100 \mathrm{~g}^{-1}\right)$ using an enzymatic test (Boehringer Mannheim, Mannheim, Germany).

\subsubsection{Sugars}

An exact amount of $1.5 \mathrm{~g}$ of yoghurt was diluted with $20 \mathrm{~mL}$ pure grade water, with $5.5 \mathrm{~mL}$ Biggs reagent added, made up to $50 \mathrm{~mL}$ with water and kept at room temperature for $1 \mathrm{~h}$ before filtering (Schleicher \& Schuell). The filtrate $(20 \mu \mathrm{L})$ was submitted to HPLC according to the FIL-IDF standard 147-B [17]. The HPLC equipment (Waters, Milford, MA, USA) consisted of a 510 pump module and 410 refractometer. Chromatographic data were processed using
Millennium $^{\mathrm{TM}}$ software (Waters). Sugar concentrations $\left(\mathrm{g} \cdot 100 \mathrm{~g}^{-1}\right)$ were calculated by the external standard method using aqueous standard solutions of lactose, glucose, galactose, fructose and sucrose (Sigma, St. Louis, MO, USA). All analyses were run in duplicate and mean values are reported.

\subsubsection{Evaluation of heat damage of yoghurt}

Furosine and galactosyl- $\beta$-pyranone levels were determined by HPLC according to Resmini and Pellegrino [34] and to Pellegrino and Cattaneo [29], respectively. Lactulose concentration was determined according to the FIL-IDF Standard [17].

\subsubsection{Isolation and characterisation of thickeners}

Isolation of thickeners was carried out according to the procedure shown in Figure 1. This procedure was modified from those reported in the literature [37] in order to improve the extraction rate of polysaccharides, especially those containing acidic monomers. Isolated polysaccharides were separated by centrifuging the hydroalcoholic suspension and then lyophilised.

Thickeners were identified by means of HPLC of the derived monomeric units (sugars and uronic acids). For this purpose, $10 \mathrm{mg}$ lyophilised polysaccharides were hydrolysed with $2 \mathrm{~mL} 2 \mathrm{~N}$ trifluoroacetic acid at $121{ }^{\circ} \mathrm{C}$ for $120 \mathrm{~min}$. An aliquot of $100 \mu \mathrm{L}$ hydrolysate was initially loaded on a $500 \mathrm{mg}-\mathrm{C} 18$ cartridge (Waters) and eluted with $2 \mathrm{~mL}$ water. The eluate was concentrated to $100 \mu \mathrm{L}$ under vacuum and loaded on a $500 \mathrm{mg}$-SAX cartridge (Waters). Elution steps were performed with $2 \mathrm{~mL}$ water followed by $2 \mathrm{~mL} 0.75 \mathrm{~N}$ sulphuric acid. The collected fractions containing sugars and uronic acids (glucuronic, mannuronic and galacturonic), respectively, were both concentrated to $100 \mu \mathrm{L}$. Sugars were determined by HPLC [17]. Uronic acids were determined by HPLC using an Aminex 87-H analytical column $(300 \times 7.8 \mathrm{~mm})($ Biorad, 
25 g yoghurt

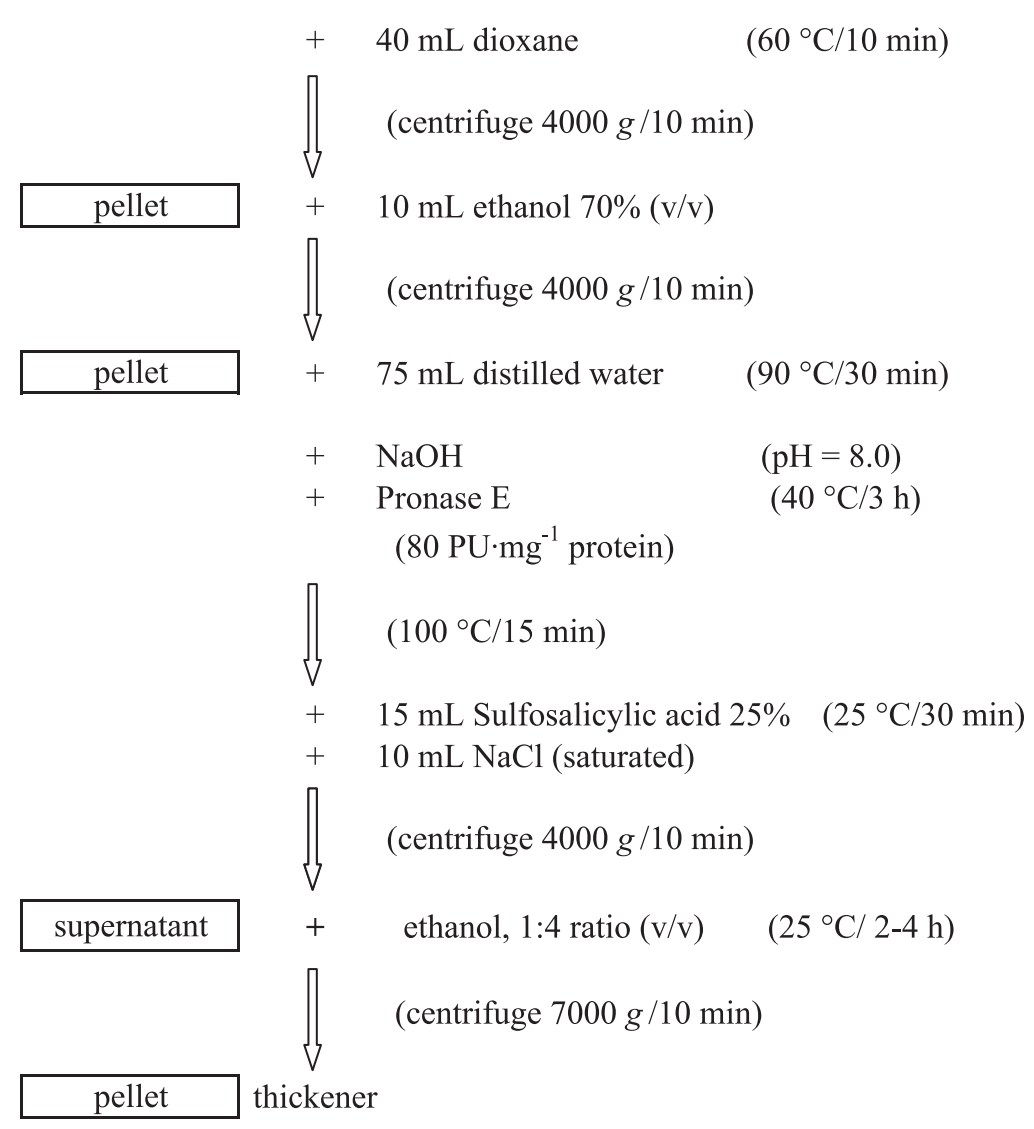

Figure 1. Analytical procedure for the extraction of thickeners from yoghurt.

Hercules, CA, USA), conditioned at $40^{\circ} \mathrm{C}$. A 40-min isocratic elution $\left(0.6 \mathrm{~mL} \cdot \mathrm{min}^{-1}\right)$ was performed with $0.01 \mathrm{~N} \mathrm{H}_{2} \mathrm{SO}_{4}$ and $\mathrm{UV}$ absorbance at $210 \mathrm{~nm}$ was recorded. Standard solutions of glucuronic, galacturonic and mannuronic acid (Sigma) were used to identify uronic acids.

Due to the possible incompleteness of both polysaccharide extraction and hydrolysis to monomeric units, quantitation of isolated thickeners was not attempted.

\subsection{Isotope ratio mass spectrometry (IRMS)}

\subsubsection{Purification of yoghurt components for IRMS}

\subsubsection{Lactic acid}

One kilogram of yoghurt (A $p, \mathrm{~A} s, \mathrm{~B} p$ and $\mathrm{N} s$ samples) was centrifuged at $6000 \times g$ at $25^{\circ} \mathrm{C}$ for $1 \mathrm{~h}$; the supernatant was filtered (Schleicher \& Schuell) and then submitted 
to ultrafiltration at $4{ }^{\circ} \mathrm{C}$ using a $3 \mathrm{~kg} \cdot \mathrm{mol}^{-1}$ cut-off membrane (Amicon, Épernon, France). About $300 \mathrm{~mL}$ permeate were collected and used for both lactic acid and sugar purification. Lactic acid was purified (from $3 \mathrm{~mL}$ permeate) by means of HPLC on an Aminex HPX-87H (Biorad) analytical column. The column was flushed with $0.02 \mathrm{~N}$ formic acid at a flow rate of $0.6 \mathrm{~mL} \cdot \mathrm{min}^{-1}$ and the eluate recorded at a $210 \mathrm{~nm}$ wavelength. Repeated injections of $50 \mu \mathrm{L}$ permeate were performed every $25 \mathrm{~min}$ and the lactic acid peak from each run was collected in a conical flask and dried under vacuum at $30^{\circ} \mathrm{C}$. The residue was dissolved with $5 \mathrm{~mL}$ water and dried again in order to completely remove formic acid.

\subsubsection{Sugars}

An aliquot of $100 \mathrm{~mL}$ yoghurt permeate was concentrated $(\times 10)$ under vacuum at $30^{\circ} \mathrm{C}$ and then held at $4{ }^{\circ} \mathrm{C}$ under gentle stirring until $(10 \mathrm{~h})$ lactose crystallisation occurred. Crystals were separated from the supernatant by centrifuging at $2000 \times g$ for 2 min and washed 3 times at $4{ }^{\circ} \mathrm{C}$ with pure grade water which was successively removed by centrifugation. Then, the lactose was dried under vacuum at $30{ }^{\circ} \mathrm{C}$ and its purity checked by HPLC [17]. In the case of sweetened samples (As and $\mathrm{N} s$ ), the supernatant from lactose crystallisation was submitted to HPLC in order to purify glucose and sucrose. The corresponding eluted peaks were collected in conical flasks and water removed by drying under vacuum at $30^{\circ} \mathrm{C}$. The purified sugars were submitted to IRMS analysis.

\subsubsection{Determination of ${ }^{13} C$ abundance by means of IRMS}

The natural abundance of ${ }^{13} \mathrm{C}$ in lactic acid, lactose, glucose and sucrose was measured using a VG SIRA II (Thermo Electron, Rodano, Italy) isotope ratio mass spectrometer able to determine the ${ }^{13} \mathrm{C} /{ }^{12} \mathrm{C}$ isotope ratio with a precision of $0.05 \%$ o using a measurement cycle of 10 or more integration periods. This apparatus was coupled to a combustion interface (Carlo Erba, Milan, Italy) which enables the sample (5-10 mg) to be burnt into carbon dioxide. The spectrometer was equipped with a triple collector for measurement of ions of different isotopomers $(\mathrm{m} / \mathrm{z}, 44,45$ and 46).

The results are expressed as $\delta$-notation in units per mil $(\% o)$ which gives the isotopic abundance of the sample with reference to the Pee Dee Belemnite (PDB) standard according to the formula:

$$
\begin{aligned}
& \delta^{13} \mathrm{C}=\left[\left({ }^{13} \mathrm{C} /{ }^{12} \mathrm{C}\right)_{\text {sample }}-\left({ }^{13} \mathrm{C} /{ }^{12} \mathrm{C}\right)_{\mathrm{PDB}}\right] \\
& 1000 /\left({ }^{13} \mathrm{C} /{ }^{12} \mathrm{C}\right)_{\mathrm{PDB}} .
\end{aligned}
$$

\subsection{Microorganism enumeration}

Microorganism enumeration was performed according to the FIL-IDF Standard 117/ISO 7889 [18]. Counts were performed in duplicate for each sample and mean values are presented.

\subsection{Statistical analyses}

The significance of the obtained data was evaluated using analysis of variance performed with StatView 5 software, version 5.0.1 (SAS Institute Inc., Cary, NC, USA).

\section{RESULTS AND DISCUSSION}

The lactose contents of concentrated milk used for manufacturing experimental skimmed and whole yoghurts are 5.80 and $5.70 \mathrm{~g} \cdot 100 \mathrm{~g}^{-1}$, respectively. Soluble carbohydrates in the final yoghurts are represented by lactose and galactose. In both the samples, levels of lactose are reduced to $3.20-3.25 \mathrm{~g} \cdot 100 \mathrm{~g}^{-1}$ after $6 \mathrm{~h}$ of fermentation at $42{ }^{\circ} \mathrm{C}$. In skimmed and whole samples, glycolytic activity of ST and LB leads to accumulation of similar amounts of lactic acid $\left(1.32\right.$ and $\left.1.25 \mathrm{~g} \cdot 100 \mathrm{~g}^{-1}\right)$ and galactose $\left(1.23\right.$ and $\left.1.18 \mathrm{~g} \cdot 100 \mathrm{~g}^{-1}\right)$. Indeed, since the catabolic activity of ST and LB mainly results in fermentation of the glucosyl moiety of lactose to produce lactic acid [36], 
Table I. Selected chemical and microbiological characteristics of commercial samples of plain yoghurt.

\begin{tabular}{|c|c|c|c|c|c|c|c|c|c|}
\hline \multirow[t]{2}{*}{$\overline{\text { Code } \dagger}$} & \multicolumn{4}{|c|}{$\begin{array}{l}\text { Residual sugars } \\
\quad\left(\mathrm{g} \cdot 100 \mathrm{~g}^{-1}\right)\end{array}$} & \multicolumn{3}{|c|}{$\begin{array}{c}\text { Lactate } \\
\left(\mathrm{g} \cdot 100 \mathrm{~g}^{-1}\right)\end{array}$} & \multicolumn{2}{|c|}{$\begin{array}{l}\text { Viable cell counts } \\
\quad\left(\mathrm{cfu} \cdot \mathrm{g}^{-1}\right)\end{array}$} \\
\hline & Lactose & Glucose & Galactose & Total & $\mathrm{D}(-)$ & $\mathrm{L}(+)$ & Total & LB & ST \\
\hline$\overline{\mathrm{A} p}$ & 2.6 & 0.0 & 1.3 & 3.9 & 0.7 & 0.6 & 1.3 & $2.6 \times 10^{8}$ & $2.0 \times 10^{8}$ \\
\hline $\mathrm{B} p$ & 4.1 & 0.0 & 1.0 & 5.1 & 0.4 & 0.7 & 1.1 & $2.5 \times 10^{7}$ & $1.9 \times 10^{8}$ \\
\hline $\mathrm{Cp}$ & 3.9 & 0.0 & 1.2 & 5.1 & 0.5 & 0.9 & 1.4 & $3.1 \times 10^{7}$ & $2.4 \times 10^{8}$ \\
\hline $\mathrm{D} p$ & 2.9 & 0.0 & 1.1 & 4.0 & 0.3 & 0.9 & 1.2 & $1.6 \times 10^{6}$ & $5.4 \times 10^{7}$ \\
\hline $\mathrm{E} p$ & 2.6 & 0.0 & 1.0 & 3.6 & 0.3 & 0.7 & 1.0 & $3.4 \times 10^{7}$ & $2.7 \times 10^{8}$ \\
\hline $\mathrm{F} p$ & 3.4 & 0.0 & 1.3 & 4.7 & 0.5 & 0.8 & 1.3 & $8.2 \times 10^{7}$ & $5.0 \times 10^{8}$ \\
\hline $\mathrm{G} p$ & 5.2 & 0.0 & 1.0 & 6.2 & 0.5 & 0.6 & 1.1 & $2.3 \times 10^{7}$ & $5.1 \times 10^{7}$ \\
\hline $\mathrm{H} p$ & 3.6 & 0.0 & 0.8 & 4.4 & 0.0 & 0.9 & 0.9 & $3.0 \times 10^{5}$ & $8.0 \times 10^{8}$ \\
\hline $\mathrm{I} p$ & 2.9 & 0.0 & 1.3 & 4.2 & 0.7 & 0.6 & 1.3 & $3.0 \times 10^{7}$ & $8.0 \times 10^{7}$ \\
\hline $\mathrm{L} p$ & 4.1 & 0.0 & 1.2 & 5.3 & 0.5 & 0.7 & 1.2 & $2.3 \times 10^{7}$ & $6.0 \times 10^{8}$ \\
\hline $\mathrm{O} p$ & 3.7 & 0.0 & 1.0 & 4.7 & 0.4 & 0.8 & 1.2 & $1.8 \times 10^{7}$ & $1.0 \times 10^{8}$ \\
\hline
\end{tabular}

$\dagger$ The capital letter in the sample code identifies the manufacturer. $¥$ Determined within $10 \mathrm{~d}$ from manufacturing.

the decrease in lactose concentration parallels the increase in lactic acid concentration which in turn equals that of unfermented galactose. Contents of sugars and lactic acid do not vary during refrigerated storage. Although thermophilic bacteria of yoghurt are unable to grow at $4-6{ }^{\circ} \mathrm{C}$, the low $\mathrm{pH}$ (3.7) of experimental yoghurts contributed most probably to the stability of sugar/lactic acid concentrations. Moreover, according to Poolman [31] and González-Andrada et al. [14], ST and LB are not capable of fermenting galactose because of the low level of the enzyme galactokinase. Lack of this enzyme suppresses the Leloir pathway through which galactose is metabolised. Consequently, this monosaccharide permeates the cell membrane in milk in a stoichiometric amount with the lactose taken up. Despite this, the presence of high amounts of galactose and low amounts of lactose can induce galactokinase [32] as demonstrated for some strains of ST [39]. Moreover, Low et al. [22] showed that a mutant strain of ST MR-1C (a gal-negative EPS-producing strain) acquired the phenotype gal+ following the loss of the capacity to synthesise EPS.

Selected chemical and microbiological characteristics determined on plain stirred yoghurts are reported in Table I. The amount of residual lactose is $3.5 \mathrm{~g} \cdot 100 \mathrm{~g} \mathrm{~g}^{-1}$ on average and the high level $\left(5.2 \mathrm{~g} \cdot 100 \mathrm{~g}^{-1}\right)$ found in $\mathrm{G} p$ yoghurt (manufactured in Germany) is probably related to the addition of skimmed milk powder to the milk base in order to increase solids-non-fat content. The level of galactose ranges from 0.8 to $1.3 \mathrm{~g} \cdot 100 \mathrm{~g} \mathrm{~g}^{-1}$ (mean $1.11 \mathrm{~g} \cdot 100 \mathrm{~g}^{-1}$ ) and, as found in experimental plain yoghurts, comparable amounts $\left(0.9-1.4 \mathrm{~g} \cdot 100 \mathrm{~g}^{-1}\right)$ of lactic acid are present.

In nine plain yoghurts $\mathrm{L}(+)$-lactate prevails over the $\mathrm{D}(-)$ isomer in agreement with the higher ST counts found in these samples [33]. Indeed, ST mainly produces $\mathrm{L}(+)$ lactic acid while $\mathrm{D}(-)$ lactic acid is typically produced by LB [38]. The $\mathrm{D}(-)$ isomer is not present in yoghurt $\mathrm{H} p$ where the viable $L B$ count is $3 \times 10^{5} \mathrm{cfu} \cdot \mathrm{g}^{-1}$, suggesting that in this sample, the LB present in the 
Table II. Selected chemical and microbiological characteristics of commercial samples of sweetened yoghurt.

\begin{tabular}{|c|c|c|c|c|c|c|c|c|c|c|c|c|c|}
\hline \multirow[t]{2}{*}{ Code $\dagger$} & \multirow[t]{2}{*}{$\begin{array}{l}\text { Added } \\
\text { sugar } \$\end{array}$} & \multicolumn{7}{|c|}{$\begin{array}{l}\text { Residual sugars } \\
\qquad\left(\mathrm{g} \cdot 100 \mathrm{~g}^{-1}\right)\end{array}$} & \multicolumn{3}{|c|}{$\begin{array}{c}\text { Lactate } \\
\left(\mathrm{g} \cdot 100 \mathrm{~g}^{-1}\right)\end{array}$} & \multicolumn{2}{|c|}{$\begin{array}{c}\text { Viable cell counts } \\
\qquad\left(\mathrm{cfu} \cdot \mathrm{g}^{-1}\right)\end{array}$} \\
\hline & & Lactose & Glucose & Salactose & Fructose & Sucrose & Total & $\begin{array}{c}\text { Total } \\
\left(\mathrm{mmol} \cdot 100 \mathrm{~g}^{-1}\right)\end{array}$ & $\mathrm{D}(-)$ & $\mathrm{L}(+)$ & Total & LB & ST \\
\hline As & SUC & 3.2 & 0.0 & 0.8 & 0,0 & 7.2 & 11.2 & 34.5 & 0.3 & 0.8 & 1.1 & $1.5 \times 10^{8}$ & $1.0 \times 10^{9}$ \\
\hline $\mathrm{B} s$ & SUC & 4.4 & 0.2 & 1.1 & 0.0 & 8.9 & 14.6 & 46.1 & 0.1 & 0.9 & 1.0 & $4.6 \times 10^{6}$ & $7.4 \times 10^{8}$ \\
\hline $\mathrm{Cs}$ & GS & 4.4 & 2.6 & 0.4 & 3.2 & 0.0 & 10.6 & 47.3 & 0.0 & 1.0 & 1.0 & $1.5 \times 10^{5}$ & $8.0 \times 10^{8}$ \\
\hline Ds & FRU & 2.8 & 0.0 & 0.6 & 6.7 & 0.0 & 10.1 & 48.7 & 0.0 & 0.9 & 0.9 & $3.6 \times 10^{5}$ & $8.4 \times 10^{8}$ \\
\hline Es & SUC & 2.0 & 1.0 & 0.9 & 0.9 & 6.9 & 11.7 & 41.6 & 0.3 & 0.8 & 1.1 & $7.0 \times 10^{6}$ & $5.0 \times 10^{8}$ \\
\hline $\mathrm{M} s$ & GS & 4.7 & 2.7 & 0.5 & 3.0 & 0.0 & 10.9 & 48.2 & 0.0 & 1.0 & 1.0 & $3.0 \times 10^{4}$ & $3.9 \times 10^{9}$ \\
\hline $\mathrm{N} s$ & $\begin{array}{c}\mathrm{SUCl} \\
\mathrm{GS}\end{array}$ & 5.6 & 1.5 & 0.4 & 0.0 & 3.3 & 10.8 & 36.6 & 0.0 & 1.2 & 1.2 & $1.7 \times 10^{6}$ & $7.5 \times 10^{8}$ \\
\hline Os & SUC & 3.4 & 1.2 & 0.7 & 1.2 & 6.0 & 12.5 & 44.7 & 0.1 & 0.9 & 1.0 & $2.0 \times 10^{6}$ & $2.0 \times 10^{8}$ \\
\hline Ps & $\begin{array}{c}\text { SUC/ } \\
\text { GS }\end{array}$ & 4.3 & 0.4 & 0.4 & 0.8 & 2.4 & 8.3 & 28.5 & 0.0 & 1.1 & 1.1 & $<10^{4}$ & $1.4 \times 10^{9}$ \\
\hline $\mathrm{Rs}$ & SUC & 4.1 & 1.6 & 0.7 & 1.2 & 4.6 & 12.2 & 44.9 & 0.0 & 0.9 & 0.9 & $1.6 \times 10^{5}$ & $5.4 \times 10^{8}$ \\
\hline Ss & SUC & 3.5 & 0.1 & 1.0 & 0.0 & 6.9 & 11.5 & 36.5 & 0.0 & 0.9 & 0.9 & $3.2 \times 10^{6}$ & $2.9 \times 10^{8}$ \\
\hline
\end{tabular}

$\dagger$ The capital letter in the sample code identifies the manufacturer. $§$ According to label (SUC $=$ sucrose, GS $=$ grape sugar, FRU = fructose). ${ }^{\ddagger}$ Determined within $10 \mathrm{~d}$ from manufacturing.

inoculated culture did not grow during yoghurt-making.

The total content of sugar in sweetened stirred yoghurts is $10-12 \mathrm{~g} \cdot 100 \mathrm{~g}^{-1}$ with the exception of $\mathrm{P} s$ and $\mathrm{B} s$ samples which show a lower $\left(8.3 \mathrm{~g} \cdot 100 \mathrm{~g}^{-1}\right)$ and higher $\left(14.6 \mathrm{~g} \cdot 100 \mathrm{~g}^{-1}\right)$ amount, respectively (Tab. II). The levels of fructose $\left(0.0-6.7 \mathrm{~g} \cdot 100 \mathrm{~g}^{-1}\right)$, glucose $\left(0.0-2.7 \mathrm{~g} \cdot 100 \mathrm{~g}^{-1}\right)$ and sucrose $\left(0.0-8.9 \mathrm{~g} \cdot 100 \mathrm{~g}^{-1}\right)$ are related to ingredients used in the formulation of the milk base. Nevertheless, fructose was not detected in yoghurt $\mathrm{N} s$ despite the fact that the addition of grape sugar was declared on the label. As already mentioned for sample $\mathrm{G} p$, the high content of lactose $\left(5.6 \mathrm{~g} \cdot 100 \mathrm{~g}^{-1}\right)$ found in yoghurt Ns manufactured in Germany probably derives from the addition of milk solids to the milk base. The average contents of galactose $\left(0.68 \mathrm{~g} \cdot 100 \mathrm{~g}^{-1}\right)$ and lactic acid (1.02 g.100 $\left.\mathrm{g}^{-1}\right)$ differ significantly from the corresponding values found in plain yoghurts (Tab. III). Moreover, lactic acid content in nine samples is higher than that of galactose by more than $0.2 \mathrm{~g} \cdot 100 \mathrm{~g}^{-1}$ (Tab. II). The L(+) isomer of lactic acid greatly predominates in sweetened yoghurts, the $\mathrm{D}(-)$ isomer being absent in seven samples. Accordingly, a strong imbalance in the ST:LB count ratio is observed and the LB count of yoghurts $\mathrm{C} s, \mathrm{D} s, \mathrm{M} s$ and $\mathrm{P} s$ is lower than $10^{6} \mathrm{cfu} \cdot \mathrm{g}^{-1}$. According to Tamime and Robinson [38] yoghurts containing more than $70 \%$ of the $\mathrm{L}(-)$ isomer can be obtained by either inoculating milk with a starter culture which mainly contains ST or carrying out the fermentation at a temperature $<40{ }^{\circ} \mathrm{C}$. In general, the ST count significantly $(P<0.05)$ differentiates sweetened from plain yoghurts (Tab. III).

It is worth noting the ST-to-LB count ratios found in yoghurts from the same producer. Similar viable counts for ST and LB are observed in As and $\mathrm{A} p$ yoghurts, while an imbalance in favour of ST characterises sweetened samples from manufacturers B, C, D and E. An unbalanced ST-to-LB count ratio in sweetened stirred yoghurts may be 
Table III. Selected chemical and microbiological characteristics of plain $(n=11)$ and sweetened yoghurts $(n=11)$ and significance value of analysis of variance $(P)$.

\begin{tabular}{lccccc}
\hline & \multicolumn{2}{c}{ plain } & \multicolumn{2}{c}{ sweetened } \\
\hline & $\times$ & $\sigma$ & $\times$ & $\sigma$ & $P$ \\
\cline { 2 - 6 } Lactate $\left(\mathrm{g} \cdot 100 \mathrm{~g}^{-1}\right)$ & 1.18 & 0.15 & 1.02 & 0.10 & $* *$ \\
Galactose $\left(\mathrm{g} \cdot 100 \mathrm{~g}^{-1}\right)$ & 1.11 & 0.16 & 0.68 & 0.25 & $* * *$ \\
$\mathrm{ST}\left(\mathrm{cfu} \cdot \mathrm{g}^{-1}\right)$ & $2.8 \times 10^{8}$ & $2.5 \times 10^{8}$ & $1.0 \times 10^{9}$ & $1.0 \times 10^{9}$ & $*$ \\
LB $\left(\mathrm{cfu} \cdot \mathrm{g}^{-1}\right)$ & $4.8 \times 10^{7}$ & $7.4 \times 10^{7}$ & $1.5 \times 10^{7}$ & $4.5 \times 10^{7}$ & $\mathrm{~ns}$ \\
Furosine $\left(\mathrm{mg} \cdot 100 \mathrm{~g}^{-1}\right.$ protein) & 112.9 & 58.8 & 122.0 & 33.2 & $\mathrm{~ns}$ \\
\hline
\end{tabular}

$* P<0.05, * * P<0.01, * * * P<0.001 ;$ ns: non significant.

related to inhibition of growth caused by high osmotic pressure conditions. Lactose accounts for about $50 \%$ of the osmotic pressure in milk, being the concentration of water-soluble molecules (lactose and salts), about $29 \mathrm{mmol} \cdot 100 \mathrm{~g}^{-1}$. This concentration increases from milk to yoghurt depending on the entity of dry matter enrichment, amount of hydrolysed lactose (i.e. content of galactose and lactic acid), type (mono- or disaccharide) and amount of added sugars. In yoghurt manufacturing, sugars are usually added to milk before heat treatment in order to get complete solubilisation along with destruction of yeasts and moulds it could contain [38]. Different studies [4, 10, 43] have evaluated metabolic behaviour of lactic acid bacteria in the presence of 10 $12 \mathrm{~g} \cdot 100 \mathrm{~g} \mathrm{~g}^{-1}$ sucrose (i.e. $29-35 \mathrm{mmol} \cdot 100 \mathrm{~g} \mathrm{~g}^{-1}$ ) and demonstrated the viability of LB strains to be dramatically depressed by high osmotic pressure of the medium. Bills et al. [3] suggested that sucrose concentration higher than $4 \mathrm{~g} \cdot 100 \mathrm{~g}^{-1}$ (i.e. $\sim 12 \mathrm{mmol} \cdot 100 \mathrm{~g}^{-1}$ ) could retard growth of yoghurt bacteria. Molar concentration of soluble sugars in sweetened yoghurts is about two- to threefold that of lactose in milk (Tab. II) and samples with the highest molar concentration $(\mathrm{C} s, \mathrm{D} s, \mathrm{M} s$ and $\mathrm{R} s$ ) show the lowest LB viable counts. Although $34.5 \mathrm{mmol}$ sugar per $100 \mathrm{~g}$ yoghurt are present, the high LB count in the As sample may be due to usage of strains with good tolerance to high osmotic pressure. An imbalance of the ST-
to-LB count ratio is also observed in Ps yoghurt which contains much less soluble sugars (i.e. $28 \mathrm{mmol} \cdot 100 \mathrm{~g}^{-1}$ ).

Glycolytic activity in plain stirred yoghurt seems not to involve galactose, the content of which approximates the level of lactic acid. As already mentioned, the induction mechanism of galactokinase can be activated [39] in the presence of high amounts of galactose and low amounts of lactose [32]. These conditions are far from those found in either plain or sweetened yoghurts. The content of galactose is lower than that of lactic acid in nine out of eleven sweetened yoghurts. Partial fermentation of the added sugars could explain the excess of lactic acid content, the origin of which was therefore investigated. Soluble sugars and lactic acid purified from $\mathrm{A} p, \mathrm{~B} p, \mathrm{~A} s$ and $\mathrm{N} s$ yoghurts were submitted to IRMS to measure the natural abundance of ${ }^{13} \mathrm{C}$. This technique is characterised by high sensitivity [5] and, according to the adopted IRMS conditions, the ${ }^{13} \mathrm{C} /{ }^{12} \mathrm{C}$ isotope ratio was determined with a precision of $0.05 \%$ o (as $\delta^{13} \mathrm{C} \%$ o notation). As shown in Table IV, the ${ }^{13} \mathrm{C} /{ }^{12} \mathrm{C}$ ratio of lactic acid from $\mathrm{A} p$ and $\mathrm{B} p$ yoghurts differs from that of the corresponding lactose by $0.86 \% \circ\left(\delta^{13} \mathrm{C} \% o\right)$. Similar differences $(0.78-0.90 \%$ o) were observed in experimental yoghurts prepared with either skimmed or whole milk (data not shown). In these yoghurts, the contents of lactic acid and galactose overlapped those recorded in 
Table IV. Carbon isotope ratio of sugars and lactate purified from plain $(p)$ and sweetened $(s)$ commercial yoghurts.

\begin{tabular}{lllll}
\hline & \multicolumn{3}{c}{$\delta^{13} \mathrm{C}(\%)$} \\
\cline { 2 - 5 } Code $\dagger$ & Lactose & Glucose & Sucrose & Lactate \\
\hline $\mathrm{A} p$ & -19.72 & & & -20.58 \\
$\mathrm{~A} s$ & -19.93 & & -27.56 & -20.52 \\
$\mathrm{~B} p$ & -24.58 & & & -25.44 \\
$\mathrm{~N} s$ & -24.80 & -26.50 & -28.00 & -24.05 \\
\hline
\end{tabular}

$\dagger$ The capital letter in the sample code identifies the manufacturer.

yoghurt Ap. On this basis, it can be assumed that the isotopic ratio of carbon is not affected by catabolism of yoghurt bacteria which, therefore, do not operate isotopomer enrichment during homolactic fermentation of lactose. It is worth noting that the same phenomenon is observed in As and $\mathrm{N} s$ yoghurts (Tab. IV), suggesting that fermentation involved lactose only, irrespective of the presence of other sugars in the milk base. Glucose in the Ns sample proves to derive from grape (declared on the label) as the ratio value $(-26.50 \%)$ is within the range of -21.5 to $-26.5 \%$ reported for this sugar [25]. Sucrose added to both As and Ns samples derives from sugar beet since the ${ }^{13} \mathrm{C} /{ }^{12} \mathrm{C}$ values $(-28.00 \%$ and $-27.56 \%$ o, respectively) are close to that of other $\mathrm{C} 3$ plants [20,35]. In these yoghurts, fermentation of a low (e.g. 20\%) amount of sucrose will result in significant (about $-1.5 \%$ ) modification of the ratio value found for lactic acid.

Although IRMS measurements did not support catabolism of added sugars by ST and LB in As and Ns yoghurts, partial fermentation of galactose to lactic acid cannot be excluded on this basis. Indeed, the same ${ }^{13} \mathrm{C} /{ }^{12} \mathrm{C}$ value characterises either glucosyl or galactosyl moiety of lactose. Consequently, fermentation of galactose will not change the carbon isotope ratio of lactic acid. Levels of galactose are lower than those of lactic acid by $0.5-0.8 \mathrm{~g} \cdot 100 \mathrm{~g}^{-1}$ in yoghurts $\mathrm{C} s, \mathrm{M} s, \mathrm{~N} s$ and $\mathrm{Ps}$ (Tab. II), all declared to contain grape sugar (sucrose is also present in $\mathrm{N} s$ and $\mathrm{Ps}$ samples). This difference is less than $0.3 \mathrm{~g} \cdot 100 \mathrm{~g}^{-1}$ in samples where only sucrose or fructose were added to the milk base. Partial fermentation of galactose was already suggested by Calvo et al. [6] in experimental yoghurts manufactured from milk base containing must (5-20 g.100 $\mathrm{g}^{-1}$ ). On the contrary, a significant decrease in either glucose or fructose from must was not observed when either 5 or $10 \mathrm{~g}$ must were added to $100 \mathrm{~g}$ milk. Conflicting results were obtained by Amoroso et al. $[1,2]$ by evaluating the sugar utilisation behaviour of ST and LB strains isolated from commercial yoghurts and grown (as single or mixed culture) with different carbon sources in non-dairy medium.

A content of galactose lower (0.2$0.8 \mathrm{~g} \cdot 100 \mathrm{~g}^{-1}$ ) than that of lactic acid seems unlikely related to EPS production since EPS were not detected in the analysed sweetened yoghurts. Although these polysaccharides mainly consist of galactose and glucose [4], their composition can be largely affected by availability of different carbon sources $[8,15,16]$. Moreover, Zisu and Shah [42] reported ST 1275 to produce a maximum of $20 \mathrm{mg}$ EPS per $100 \mathrm{~mL}$ after $12 \mathrm{~h}$ of incubation at $37^{\circ} \mathrm{C}$ in reconstituted skimmed milk without $\mathrm{pH}$ adjustment. Taking into account this feature, the adopted procedure particularly intended for thickener extraction could not be selective for a low level of EPS. On this basis, the presence of negligible amounts of EPS in the studied yoghurts cannot be excluded.

It is interesting to note that the carbon isotope ratios of both lactose and lactic acid from $\mathrm{B} p$ and $\mathrm{N} s$ yoghurts are significantly different from those characterising the same compounds extracted from A $p$ and As samples (Tab. IV). In this regard, these differences indicate the potential of the ${ }^{13} \mathrm{C}$ level as a marker of cow's feed components $[5,35]$. Indeed, $\mathrm{A} p$ and $\mathrm{As}$ samples were prepared from milk produced in the plain areas of Northern Italy where cows are 
mainly fed on corn silage. Hence, the typical isotope ratio value of $\mathrm{C} 4$ plants is observed for lactose. The lower value of ${ }^{13} \mathrm{C}$ of lactose isolated from $\mathrm{B} p$ and $\mathrm{N} s$ yoghurts could be attributed to feeding based on hay and pasture (C3 Gramineae) adopted in Trentino (a mountain region of Italy) and in Bavaria (Germany) where these yoghurts were, respectively, manufactured.

Due to the mentioned restrictive regulations [9], yoghurt produced in Italy must be tested for the presence of thickeners. Extraction of thickeners from yoghurt is hindered by the firm network of denaturated protein in which they are entrapped. Moreover, the presence of even a negligible amount of lactose in extracted thickeners impairs their identification which is based on the determination of monomeric units (including glucose and galactose) released on acid hydrolysis. Adoption of the procedure described in Figure 1 and resulting from the combination of different methods reported in the literature [37] allowed us to recover thickeners as pure (lactose-free) compounds. Two sweetened yoghurts (Os and $\mathrm{R} s$ ) proved to contain pectin because galacturonic acid, rhamnose, galactose, xylose and arabinose were detected in the acid hydrolysate. No thickeners were extracted from yoghurt $\mathrm{Ss}$ while addition of iodine solution $\left(\mathrm{I}^{-} / \mathrm{I}_{2}, 0.1\right.$ $\mathrm{mol} \cdot \mathrm{L}^{-1}$ ) to this sample demonstrated the presence of starch. Due to its chemical and physical characteristics, this polysaccharide could not be isolated following the described procedure.

The effects of milk base heating have been widely studied with respect to both the rheological properties of yoghurt and growth of lactic acid bacteria [38]. Nevertheless, the time/temperature conditions adopted in milk base preparation promote extensive protein glycosylation and crosslinking phenomena which can impair the availability of some amino acids (e.g. lysine) [12]. In this regard, evaluation of heat damage could represent an additional analytical tool for characterisation of yoghurt quality.
The levels of molecules arising from early (furosine, FUR) or advanced (galactosyl- $\beta$-pyranone, GAP) stages of the Maillard reaction as well as from lactose epimerisation (lactulose) were determined in both experimental and commercial yoghurts. The former were obtained by culturing either skimmed or whole milk heattreated at $90{ }^{\circ} \mathrm{C}$ for $30 \mathrm{~min}$ (see Materials and Methods). Samples were also taken during the heating of the milk base at 5, 10, 20 and $30 \mathrm{~min}$. The related levels of the heat damage indicators are given in Figure 2. FUR content increases over the heating time-period and it reaches 187 and $247 \mathrm{mg} \cdot 100 \mathrm{~g}^{-1}$ protein in skimmed and whole milk, respectively, after $30 \mathrm{~min}$ of heat treatment. Similar levels are found in the corresponding yoghurts, indicating that the fermentation conditions $\left(42{ }^{\circ} \mathrm{C}\right.$ for $\left.6 \mathrm{~h}\right)$ were ineffective towards protein glycosylation. The GAP and lactulose contents of the concentrated milk base behave similarly upon heating but their levels decrease in finished yoghurts. GAP reduction (10-30\%) is probably due to the low $\mathrm{pH}$ value of the medium, as demonstrated by Pellegrino et al. [29], while lactulose was partially (20-40\%) fermented as clarified by further experiments (data not shown). As expected, heat damage is lower in samples from whole milk due to the protective effect exerted by fat [28]. Table V shows the levels of GAP, FUR and lactulose in commercial yoghurts. As previously suggested, only the level of FUR represents a reliable indicator of heat damage in yoghurt, the GAP and lactulose levels being possibly underestimated. The FUR level is not distinctive of the two types of yoghurts (Tab. III) and very different heat damage is observed within each group. This demonstrates that heating conditions may vary widely at an industrial level even when similar manufacturing processes, such as those adopted for plain yoghurt, are applied. Some samples (A $p, \mathrm{~F} p, \mathrm{G} p, \mathrm{H} p$, I $p$, $\mathrm{A} s, \mathrm{D} s, \mathrm{M} s$, $\mathrm{N} s$ and $\mathrm{P} s$ ) show FUR contents comparable with those which characterise indirect UHT milk [30]. 


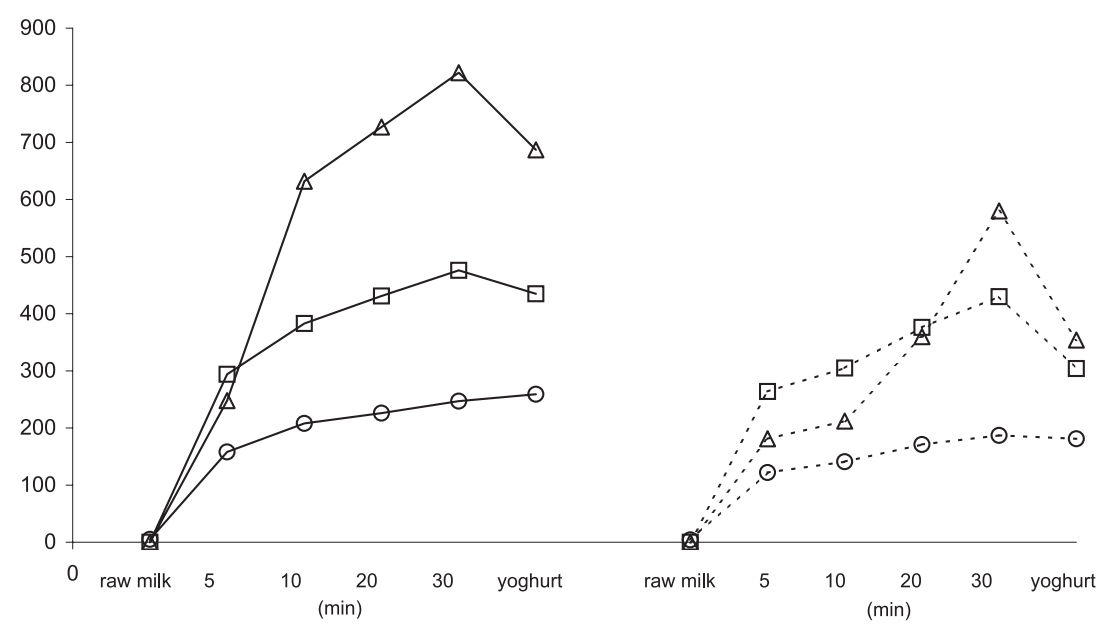

Figure 2. Levels of lactulose $\left(\square, \mathrm{mg} \cdot \mathrm{L}^{-1}\right)$, furosine $\left(O, \mathrm{mg} \cdot 100 \mathrm{~g}^{-1}\right.$ protein $)$ and galactosyl- $\beta$-pyranone $\left(\triangle, \mathrm{nmol} \cdot 100 \mathrm{~mL}^{-1}\right)$ in $(-)$ skimmed or $(---)$ whole milk heated at $90{ }^{\circ} \mathrm{C}$ for different times and in the yoghurts from milk heated at $90{ }^{\circ} \mathrm{C}$ for $30 \mathrm{~min}$.

Table V. Levels of furosine, galactosyl- $\beta$-pyranone (GAP) and lactulose in commercial samples of yoghurt.

\begin{tabular}{|c|c|c|c|c|}
\hline \multirow[t]{2}{*}{ Code $\dagger$} & \multirow[t]{2}{*}{ Type } & Furosine & \multirow{2}{*}{$\frac{\text { GAP }}{\left(\mathrm{nmol} \cdot 100 \mathrm{~mL}^{-1}\right)}$} & \multirow{2}{*}{$\frac{\text { Lactulose }}{\left(\mathrm{mg} \cdot \mathrm{L}^{-1}\right)}$} \\
\hline & & $\left(\mathrm{mg} \cdot 100 \mathrm{~g}^{-1}\right.$ protein $)$ & & \\
\hline$\overline{A p}$ & skimmed & 187 & 217 & 317 \\
\hline $\mathbf{B} p$ & full fat & 44 & 15 & 39 \\
\hline Cp & full fat & 44 & 15 & 39 \\
\hline $\mathrm{D} p$ & full fat & 66 & 29 & 114 \\
\hline Ep & full fat & 62 & 31 & 95 \\
\hline $\mathbf{F p}$ & full fat & 147 & 126 & 177 \\
\hline $\mathbf{G} p$ & full fat & 153 & 42 & 103 \\
\hline Нp & full fat & 155 & 104 & 140 \\
\hline $\mathbf{I} p$ & skimmed & 208 & 126 & 347 \\
\hline $\mathbf{L p}$ & full fat & 88 & 16 & 98 \\
\hline Op & skimmed & 88 & 41 & 22 \\
\hline As & full fat & 172 & 420 & 434 \\
\hline Bs & full fat & 128 & 15 & 48 \\
\hline $\mathrm{Cs}$ & full fat & 85 & 14 & 50 \\
\hline Ds & full fat & 159 & 80 & 221 \\
\hline Es & full fat & 100 & 42 & 205 \\
\hline Ms & full fat & 144 & 19 & 160 \\
\hline $\mathbf{N s}$ & full fat & 142 & 80 & 122 \\
\hline Os & full fat & 67 & 20 & 106 \\
\hline Ps & full fat & 143 & 93 & 163 \\
\hline $\mathbf{R s}$ & full fat & 100 & 101 & nd \\
\hline Ss & full fat & 102 & 35 & 113 \\
\hline
\end{tabular}

$\dagger$ The capital letter in the sample code identifies the manufacturer. 


\section{CONCLUSION}

The taste and texture characteristics of sweetened stirred yoghurts seem to meet the preferences of Italian consumers. Despite this, a strong imbalance in the ST-to-LB count ratio is observed in many of these yoghurts, which therefore should not be considered as yoghurt, i.e. fermented milk containing symbiotic culture of ST and LB. Moreover, the optimal texture and viscosity of yoghurt are sometimes achieved by the illegal addition of thickeners to the milk base.

Despite the presence of other easily fermentable sugars, glycolitic activity in two of the commercial sweetened yoghurts seems to involve lactose only. This observation is based on the comparison of the carbon isotope ratio of lactose and lactic acid extracted from these yoghurts. The low levels of residual galactose generally found in sweetened samples can hardly be related to EPS production by the starter culture. More probably, partial metabolism of this sugar could be hypothesised. Nevertheless, further investigations are needed in order to clarify if modified fermentation patterns may occur in sweetened milk base. Regardless of sweetening, commercial yoghurts show significant heat damage. Although heating of milk is paramount for improving the firmness and texture of yoghurt, the levels of xenobiotic molecules suggest that (industrial) processing conditions should be better defined.

Acknowledgments: We wish to thank Professor P. Resmini from our department for helpful discussion and Dr. G. Versini from the Istituto Tecnico Agrario S. Michele all'Adige (Trento, Italy) for performing IRMS analyses.

\section{REFERENCES}

[1] Amoroso M.J., Manca de Nadra M.C., Oliver G., Glucose, galactose, fructose, lactose and sucrose utilisation by Lactobacillus bulgaricus and Streptococcus thermophilus isolated from commercial yogurt, Milchwissenschaft 43 (1988) 626-631.

[2] Amoroso M.J., Manca de Nadra M.C., Oliver G., The growth and sugar utilisation by Lactobacillus delbrueckii ssp. bulgaricus and
Streptococcus salivarius ssp. thermophilus isolated from market yogurt, Lait 69 (1989) 519-528.

[3] Bills D.D., Yang C.S., Morgan M.E., Bodyfelt F.W., Effect of sucrose on the production of acetaldehyde and acids by yogurt culture bacteria, J. Dairy Sci. 55 (1972) 1570-1573.

[4] Bottazzi V., Other fermented dairy products, Biotechnology 5 (1983) 315-363.

[5] Brand W.A., High precision isotope ratio monitoring techniques in mass spectrometry, J. Mass Spectrom. 31 (1996) 225-235.

[6] Calvo M.M., Ordonez J.A., Olano A., The use of grape must in the elaboration of yoghurt. Changes of carbohydrate composition during manufacture, Milchwissenschaft 50 (1995) 506-508.

[7] Cerning J., Production of exopolisaccharides by lactic acid bacteria and propionibacteria, Lait 75 (1995) 463-472.

[8] Cerning J., Renard C.M.G.C., Thibault J.F., Bouillanne C., Landon M., Desmazeaud M., Topisirovic L., Carbon source requirements for exopolisaccharide production by Lactobacillus casei CG11 and partial structure analysis of the polymer, Appl. Environ. Microbiol. 60 (1994) 3914-3919.

[9] Circolare Ministero Sanità n. 9 del 3/2/1986, Preparazioni lattee speciali, 1986.

[10] Cislaghi S., Chirico D., Pirovano F., Sozzi T., Effect of saccharose on the growth of yoghurt cultures, L'Industria del Latte 30 (1994) 55-71.

[11] Corredig M., Dalgleish D.G., The mechanisms of the heat induced interactions of whey protein with casein micelles in milk, Int. Dairy J. 9 (1999) 233-236.

[12] De Noni I., Il significato analitico delle modificazioni proteiche nel latte e derivati, Latte 10 (2001) 102-107.

[13] FAO/WHO, Codex Alimentarius Commission, 26th Session, "Report of the 5th session of the Codex Committee on milk and milk products" - Draft Revised Standard for Fermented Milks, (2000). Available: http:// www.codexalimentarius.net/reports.asp

[14] Gonzales-Andrada J.I., Romero C., Morales F.J., Jimenez-Perez S., An improved method for determination of the activity of $\beta$-galactosidase in yoghurt by high-performance liquid chromatography, Chromatographia 43 (1996) 85-88.

[15] Grobben G.J., Smith M.R., Sikkema J., de Bont J.A.M., Influence of fructose and glucose on the production of exopolysaccharides and the activities of enzymes involved in the sugar metabolism and the synthesis of sugar nucleotides in Lactobacillus delbrueckii subsp. bulgaricus NCFB 2772, Appl. Microbiol. Biotechnol. 3 (1996) 279-284. 
[16] Grobben G.J., van Casteren W.H.M., Schols H.A., Oosterveld A., Sala G., Smith M.R., Sikkema J., de Bont J.A.M., Analysis of the exopolysaccharides produced by Lactobacillus delbrueckii subsp. bulgaricus NCFB 2772 grown in continuous culture on glucose and fructose, Appl. Microbiol. Biotechnol. 4 (1997) 516-521.

[17] IDF, Heat-treated milk - Determination of lactulose content. Method using high-performance liquid chromatography, Standard IDF 147 B, Int. Dairy Fed., Brussels, Belgium, 1998.

[18] IDF, Yoghurt - Enumeration of characteristic microorganisms. Colony count technique at $37^{\circ} \mathrm{C}$, Standard $117 / \mathrm{ISO} 7889$, Int. Dairy Fed., Brussels, Belgium, 2003.

[19] Kneifel W., Jaros D., Erhard F., Microflora and acidification properties of yogurt and yogurt-related products fermented with commercially available starter cultures, Int. J. Microbiol. 18 (1993) 179-189.

[20] Kornexl B.E., Werner T., Roßmann A., Schimdt H.L., Measurement of stable isotope abundances in milk and milk ingredients - a possible tool for origin assignment and quality control, Z. Lebens. Unters. Forsch. 205 (1997) 19-24.

[21] Laws A.P., Marshall V.M., The relevance of exopolysaccharides to the rheological properties in milk fermented with ropy strains of lactic acid bacteria, Int. Dairy J. 11 (2001) 709-721.

[22] Low D., Ahlgren J.A., Horne D., McMahon D.J., Oberg C.J., Broadbent J.R., Role of Streptococcus thermophilus MR-1C capsular exopolysaccharide in cheese moisture retention, Appl. Environ. Microbiol. 6 (1998) 2147-2151.

[23] Lucey J.A., Tet Teo C., Munro P.A., Singh H., Rheological properties at small (dynamic) and large (yeld) deformations of acid gels made from heated milk, J. Dairy Res. 4 (1997) 591-600.

[24] Matalon M.E., Sandine W.E., Lactobacillus bulgaricus, Streptococcus thermophilus and yogurt: a review, Cult. Dairy Prod. J. 21 (1986) 6-12.

[25] Meier-Augenstein W., The chromatographic side of isotope ratio mass spectrometry: pitfalls and answers, LC-GC 1 (1997) 17-25.

[26] Monnet V., Condon S., Cogan T.M., Gripon J.C., Metabolism of starter cultures, in: Cogan T.M., Accolas J.P. (Eds.), Dairy Starter Culture, VCH, New York, USA, 1995, pp. 47-95.

[27] Mottar J., Bassier A., Joniau M., Baert J., Effect of heat induced association of whey protein and casein micelles on yogurt texture, J. Dairy Sci. 9 (1989) 2247-2256.
[28] Pellegrino L., Influence of fat content on some heat-induced changes in milk and cream, Neth. Milk Dairy J. 48 (1994) 71-80.

[29] Pellegrino L., Cattaneo S., Occurrence of galactosyl isomaltol and galactosyl- $\beta$-pyranone in commercial drinking milk, Nahrung 45 (2001) 195-200.

[30] Pellegrino L., De Noni I., Resmini P., Coupling of lactulose and furosine indices for quality evaluation of sterilized milk, Int. Dairy J. 5 (1995) 647-659.

[31] Poolman B., Energy transduction in lactic acid bacteria, FEMS Microbiol. Rev. 12 (1993) 125-148.

[32] Poolman B., Royer T.J., Mainzer S.E., Schmidt B.F., Carbohydrate utilization in Streptococcus thermophilus: characterization of genes for aldose 1-epimerase (mutarotase) and UDP glucose 4-epimerase, J. Bacteriol. 172 (1990) 4037-4047.

[33] Rasïc J.L., Kurmann J.A., Yoghurt, scientific grounds, technology, manufacture and preparations, Technical Dairy Publishing House, Copenhagen, Denmark, 1978.

[34] Resmini P., Pellegrino L., Accurate quantification of furosine in milk and dairy products by direct HPLC method, Ital. J. Food Sci. 3 (1990) 173-183.

[35] Roßmann A., Kornexl B., Versini G., Pichlmayer F., Lamprecht G., Origin assignment of milk from Alpine regions by multielement stable isotope ratio analysis (Sira), Riv. Sci. Aliment. 27 (1998) 9-21.

[36] Salminen S., von Wright A., Lactic Acid Bacteria, Microbiology and Functional Aspects, Marcel Dekker, New York, USA, 1998.

[37] Scherz H., Bonn G., Analytical chemistry of carbohydrates, G. Thieme Verlag, Stuttgart, Germany, 1998.

[38] Tamime A.Y., Robinson R.K., Yoghurt: Science and Technology, CRC Press, Boca Raton, USA, 1999.

[39] Tinson W., Hillier A.J., Jago G.R., Metabolism of Streptococcus thermophilus, Aust. J. Dairy Technol. 37 (1982) 8-25.

[40] Torriani S., Vescovo M., Dicks L.M.T., Streptococcus thermophilus and Lactobacillus delbrueckii subsp. bulgaricus: a review, Ann. Microbiol. Enzymol. 47 (1997) 29-52.

[41] Troiani C., Innovazione e segmentazione spingono lo yogurt, Latte 4 (1999) 40-42.

[42] Zisu B., Shah N.P., Effects of pH, temperature, supplementation with whey protein concentrate, and adjunct cultures on the production of exopolysaccharides by Streptococcus thermophilus 1275, J. Dairy Sci. 86 (2003) 3405-3415.

[43] Zourari A., Accolas J.P., Desmazeaud M.J., Metabolism and biochemical characteristics of yogurt bacteria. A review, Lait 72 (1992) $1-34$. 